Journal of Environmental Sciences (JES)

Faculty of Graduate Studies and Environmental Research, Ain Shams University

El-Gebaly et al.

\title{
MIGRATION PARAMETERS OF SOARING BIRDS CROSSING WIND FARMS OF GABEL AL-ZEIT CORRIDOR ON THE RIFT VALLEY/RED SEA FLYWAY, EASTERN DESERT, EGYPT
}

\author{
Osama A. El Gebaly ${ }^{(1)}$; Sohail S. Soliman ${ }^{(2)}$ and Moustafa M. Fouda ${ }^{(3)}$ \\ 1) Ministry of Environment 2) Faculty of Science, Ain Shams University
}

\begin{abstract}
Egypt includes a great part of the Great Rift Valley/Red Sea flyway; the second world's most important flyway for migratory soaring birds. It acts as a corridor between Eurasia and Africa. The aim of the present study is to study the phenology and survey the numbers of species and individuals of migratory soaring birds that pass through a wind farm (240 Megawatts (MW) wind energy project of Kreditanstalt für Wiederaufbau (Germany's development bank) (KFW) located in Gebel Al-Zeit area, Red Sea Governorate, Egypt. Bird monitoring was conducted by visual observations, for eight hours during daytime at the whole survey period in two fixed observation points, during the period extending from March $4^{\text {th }}$ to May $10^{\text {th }}$, 2018. This observation period covered a four-week peak of spring migration season. A total of 143,906 soaring birds belonging to 32 species were counted. The most common bird species was the white stork $(63.1 \%)$, the northern steppe buzzard/common buzzard (13.21\%), the great white pelican (7.42\%), the European honey buzzard (6\%), the Levant sparrowhawk $(2.38 \%)$, and the black kite, $(2.17 \%)$. Globally threatened (vulnerable, endangered, and critically endangered) migratory soaring bird species recorded in the study area surpassed $1 \%$ of the flyway population. These species include the Egyptian vulture (1.2\%) and the steppe eagle (3.02\%). Two other near threatened bird species; i.e., the pallid harrier (6 individuals), and the red-footed falcon (two individuals), were also observed. These results

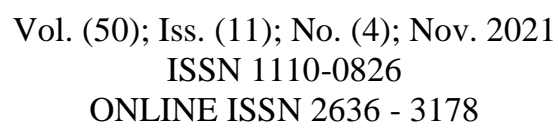


spotlight on the importance of protecting the study area as a bird migration corridor.

Keywords: migratory soaring birds, wind farms, Rift Valley/Red Sea flyway, Gabel Al-Zeit, spring migration, flyway population, steppe eagle, white stork.

\section{INTRODUCTION}

Egypt includes a great part of the Great Rift Valley/Red Sea flyway; the second world's most important flyway for migratory soaring birds. It acts as a corridor between Eurasia and Africa, and is characterized by wide geographical, geological, and meteorological variations with sporadic urban and religious establishments, and scattered human societies (Riad, 2019; Riad \& Mahmoud, 2020). It is an important passage for migrating soaring birds between Eurasian breeding grounds and African wintering grounds (Bergen, 2007; CarlBro, 2010; Bergen \& Gaedicke, 2013).

At the core of the Rift Valley/Red Sea Flyway lies the Gulf of Suez with few bottlenecks represented by Gabel Al Zeit, Suez, Ain Sukhna, Ras Mohamed National Park, and the Qaa' Plain, which are universally perceived as Important Bird Areas (IBAs) (Baha El Din, 1999). Hundreds of thousands of migrating raptors, storks, and pelicans pass each autumn and from their breeding areas in Eurasia to sub-Saharan Africa, where they spend the winter, and then return back in the next spring to their homelands (Moreau, 1972).

Migratory birds face extremely hard conditions as they cross extensive areas of seas and deserts. The greater part of bird species, especially small ones, perform immediate and active flights, choosing the shortest way 368 
between breeding and wintering grounds (Riad et al. 2019). Soaring birds, on the other hand, are almost entirely dependent on the updraft of warm air to sustain their migration trip which greatly reduces their free choice of migration routes and restricts them along very narrow ones. The lack of updrafts over large areas of water prevents them from flight over water except at the narrowest of straits (Newton, 2008). Many soaring birds that migrate to and from East Africa even avoid crossing the Gulf of Suez and convolute via Suez instead. Other birds that migrate to Sinai in spring converge at Zeit Bay because it is the narrowest crossing point in the southern part of the Gulf of Suez.

Globally threatened species such as eastern imperial eagle, (vulnerable), greater spotted eagle, (vulnerable), Egyptian vulture (endangered) and the near threatened pallid harrier, are known to migrate through this area. The most numerous species reported over the Eastern Desert of Egypt include the white stork, and the Levant sparrowhawk, (Baha El Din, 1999). The main migration route of the white stork passes through Zeit Bay, and the entire world population of the Levant sparrowhawk migrate through this area, usually in large flocks, in few days (Baha El Din, 1999; Schulz, 1988; Berthold et al. 2001).

The main migration corridors through Egypt are still not precisely identified because there have been no synchronous migration studies across the whole width of the flyway, and the total number of soaring birds that fly through Egypt is still to be determined accurately. In the present study, data 
were collected on the species, number, altitude and direction of soaring birds during their spring migration between the African and Eurasian grounds across the part of the Great Rift valley/Red Sea flyway that lies in Egypt.

\section{MATERIALS AND METHODS}

Study area: The study site is the KFW $240 \mathrm{MW}$ wind farm, located on the Red Sea coastal plain that stretches between Sabkhet Ras Shukhair and the foothills of the Red Sea Mountains. It is located on the western bank of the Gulf of Suez, about $10 \mathrm{~km}$ away from Ras Shukair, $120 \mathrm{~km}$ to the north of Hurghada, and about 5km to the West of the Hurghada - Suez Road (Fig. 1). It has a total area of about $38.5 \mathrm{~km}^{2}$ with a maximum extension of about $6.5 \mathrm{~km}$ (west to east) and about $9.3 \mathrm{~km}$ (south to north) of the KFW wind farm. The eastern part of the site is flat or slightly undulating, with increased elevation and topographic complexity in the western part.

There are 120 wind turbines arranged in seven parallel arrays and are oriented from the northeast to the southwest. The distance between adjacent arrays is about $1.1 \mathrm{~km}$ and the longest array is $5.2 \mathrm{~km}$ long. A $220-\mathrm{kV}$ power line runs along the eastern perimeter of the wind farm (Fig. 1). The study area was partially monitored, only 8 hours on a daily basis in spring migration (from March $4^{\text {th }}-$ May $10^{\text {th }}, 2018$

Observation technique: Visual observations were carried out during daylight hours from March $4^{\text {th }}$ to May 10 ${ }^{\text {th }}$, 2018, (four-weeks) which represent the peak of spring migration season in Egypt. The standard 370 
technique for bird enumeration followed the Scottish Natural Heritage guidance (SNH, 2010) and the methodology described in Sutherland (2006). Bird monitoring was conducted from two fixed observation points, and observation posts were positioned to provide the best visual coverage of the bird's movements. Each vantage point almost completely covered about $2500 \mathrm{~m}$ view scope within each selected point in the study area.

The survey covered all point watches for 8 hours/day, 7 days/weekly, from 8:00 a.m. to 16:00 p.m. with an hour break. Bird altitude was recorded using the turbine height as an indicator at time intervals of fifteen seconds, weather conditions (wind direction and speed, temperature, cloud/mist, rains, and visibility) were recorded hourly according to the method followed by Riad (2019). The researcher at each point was supplied by professional binoculars, digital cameras, bird identification filed guide, clipboards, compass and recording sheets and maps. 


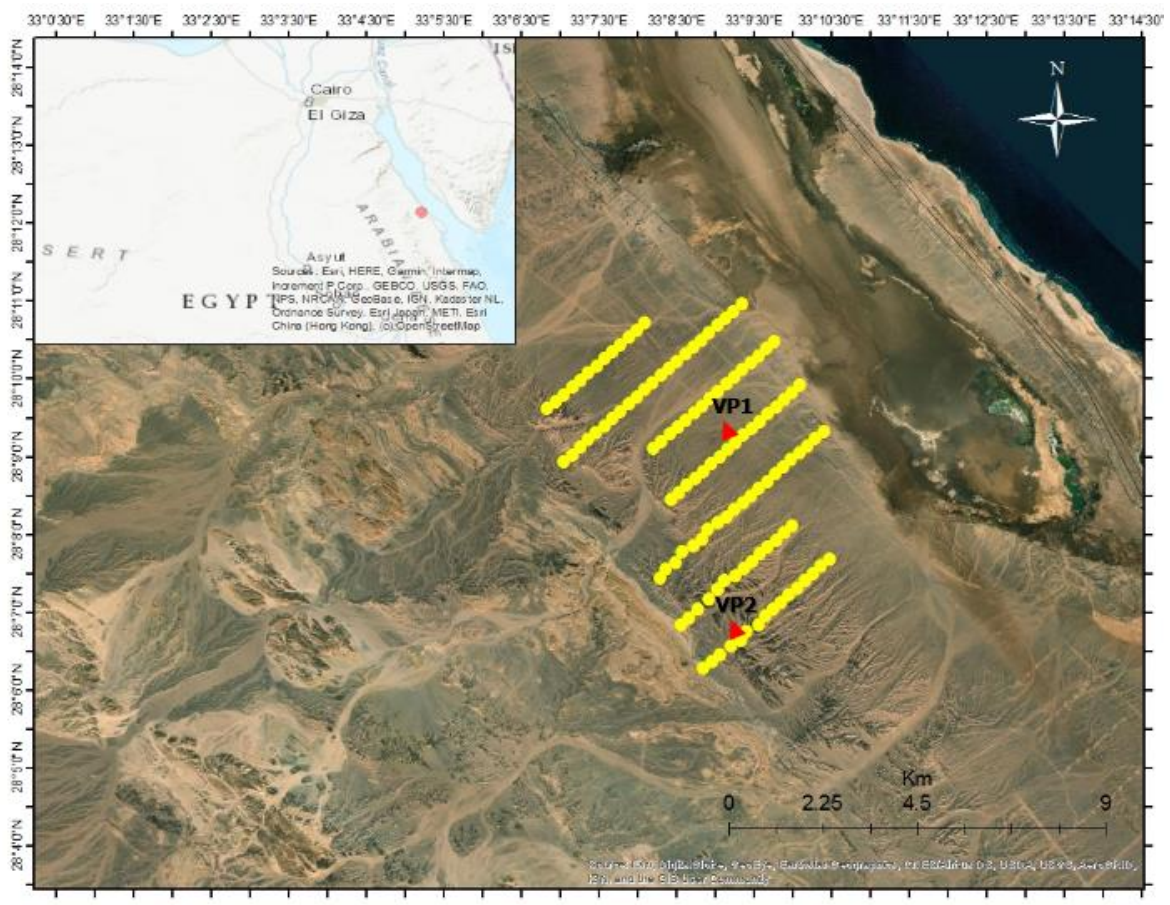

Fig. (1): A map showing turbines distribution in the study area (VP1 and VP2).

\section{RESULTS}

Bird numbers and bird records: A sum of 456 survey hours for each of the two vantage points (a total of 912 observation hours for the whole study area) were completed in the field during the study period, generally 4 hours in the daily morning session and 4 in the afternoon session. A total of 143,906 individual birds belonging to thirty-two migratory soaring bird species were recorded during the standard field observations carried out from March $4^{\text {th }}$ to 
May $10^{\text {th }}, 2018$ (Table 1). Four common bird species formed about $90 \%$ of the total recorded number. They included the white stork $(63.03 \%)$, the steppe buzzard/common buzzard (13.21\%), the white pelican (7.42\%), and the honey buzzard $(6.01 \%)$. The remaining 28 bird species were rare ones since they formed $10 \%$ of the recorded species. The number of records (observations) of a given bird species is not necessarily proportional to its total number during these records. For example, the black kite is one of the rare bird species, however, the number of its records formed $(12.51 \%)$ of the total number of records. Other bird species which were frequently recorded were the steppe buzzard/common buzzard (39.46\%), the steppe eagle (11.16\%), and honey buzzard (8.93\%). All globally threatened (vulnerable, endangered, and critically endangered) migratory soaring species recorded in the study area surpassed $1 \%$ of the flyway population. These species include the Egyptian vulture $(1.2 \%)$, the steppe eagle $(3.02 \%)$. Two other near-threatened bird species; i.e., the pallid harrier and the red-footed falcon were recorded. Only 6 individuals of the first species and two individuals of the second one were observed. 
Journal of Environmental Sciences (JES)

Faculty of Graduate Studies and Environmental Research, Ain Shams University

El-Gebaly et al.

Table (1): English names, scientific names, number of individuals, number of records, minimum and maximum observed number of birds, and percentages of numbers and records of bird species observed in the study area during spring 2018

\begin{tabular}{||c|c|c|c|c|c|c|c|c||}
\hline \hline No & English name & Scientific name & B. No. & R. No. & Min. & Max. & $\%$ Birds & \% Records \\
\hline \hline 1 & White Pelican & Pelecanus onocrotalus & 8678 & 33 & 4 & 1200 & 7.42 & 0.88 \\
\hline 2 & White Stork & Ciconia Ciconia & 92706 & 135 & 1 & 12000 & 63.03 & 3.59 \\
\hline 3 & Black Stork & Ciconia nigra & 916 & 53 & 1 & 190 & 0.64 & 1.41 \\
\hline 4 & Eleonora's Falcon & Falco eleonorae & 2 & 2 & 1 & 1 & 0.00 & 0.05 \\
\hline 5 & Great Cormorant & Phalacrocorax carbo & 364 & 4 & 22 & 90 & 0.25 & 0.11 \\
\hline 6 & Egyptian Vulture & Neophron percnopterus & 60 & 27 & 1 & 3 & 0.04 & 0.72 \\
\hline 7 & Osprey & Pandion haliaetus & 18 & 12 & 1 & 2 & 0.01 & 0.32 \\
\hline 8 & Eastern Imperial Eagle & Aquila heliacal & 54 & 38 & 1 & 2 & 0.04 & 1.01 \\
\hline 9 & Lesser Spotted Eagle & Aquila pomarine & 442 & 141 & 1 & 2 & 0.31 & 3.75 \\
\hline 10 & Greater Spotted Eagle & Aquila clanga & 6 & 5 & 1 & 1 & 0.00 & 0.13 \\
\hline 11 & Steppe Eagle & Aquila nipalensis & 1298 & 419 & 1 & 11 & 0.90 & 11.16 \\
\hline 12 & Short-toed Eagle & Circaetus gallicus & 160 & 90 & 1 & 4 & 0.11 & 2.40 \\
\hline 13 & Booted Eagle & Hieraaetus pennatus & 100 & 57 & 1 & 5 & 0.07 & 1.52 \\
\hline 14 & Common Crane & Grus grus & 80 & 1 & 40 & 40 & 0.06 & 0.03 \\
\hline 15 & Marsh Harrier & Circus aeruginosus & 28 & 21 & 1 & 1 & 0.02 & 0.56 \\
\hline 16 & Montagu's Harrier & Circus pygargus & 6 & 5 & 1 & 1 & 0.00 & 0.13 \\
\hline \hline
\end{tabular}


Cont. Table (2):

\begin{tabular}{||c|c|c|c|c|c|c|c|c||}
\hline \hline No & English name & Scientific name & B. No. & R. No. & Min. & Max. & \% Birds & \% Records \\
\hline \hline 17 & Pallid Harrier & Circus macrourus & 6 & 5 & 1 & 1 & 0.00 & 0.13 \\
\hline 18 & Long-legged Buzzard & Buteo rufinus & 234 & 114 & 1 & 7 & 0.16 & 3.04 \\
\hline 19 & Steppe Buzzard/common buzzard & Buteo buteo vulpinus & 19012 & 1482 & 1 & 450 & 13.21 & 39.46 \\
\hline 20 & European Honey Buzzard & Pernis apivorus & 8646 & 336 & 1 & 330 & 6.01 & 8.93 \\
\hline 21 & Eurasian Sparrowhawk & Accipiter nisus & 122 & 45 & 1 & 8 & 0.08 & 1.20 \\
\hline 22 & Levant Sparrowhawk & Accipiter brevipes & 3422 & 21 & 1 & 600 & 2.39 & 0.56 \\
\hline 23 & Kestrel & Falco tinnunculus & 38 & 24 & 1 & 2 & 0.03 & 0.64 \\
\hline 24 & Lesser Kestrel & Falco naumanni & 8 & 6 & 1 & 1 & 0.01 & 0.16 \\
\hline 25 & Red-footed Falcon & Falco vespertinus & 2 & 2 & 1 & 1 & 0.00 & 0.05 \\
\hline 26 & Hobby & Falco Subbuteo & 3 & 3 & 1 & 1 & 0.00 & 0.08 \\
\hline 27 & Yellow billed kite & Milvus migrans aegyptius & 2 & 1 & 1 & 1 & 0.00 & 0.03 \\
\hline 28 & Black Kite & Milvus migrans & 3120 & 470 & 1 & 120 & 2.17 & 12.51 \\
\hline 29 & Raptor sp. & Accipitridae sp. & 1302 & 90 & 1 & 100 & 0.90 & 2.40 \\
\hline 30 & Eagle sp. & Aquila sp. & 210 & 33 & 1 & 40 & 0.15 & 0.88 \\
\hline 31 & Harrier sp. & Circus sp. & 81 & 6 & 1 & 1 & 0.06 & 0.16 \\
\hline 32 & Buzzard sp. & Buteo/Pernis sp. & 2780 & 75 & 1 & 550 & 1.93 & 2.00 \\
\hline & Total & & 143906 & 3756 & & & 100.00 & 100.00 \\
\hline \hline
\end{tabular}

Sp.: Species; B. No: Numbers of Birds; R. No.: Numbers of bird records; \%: percentage; Min: Minimum; Max, Maximum.

Flock size: In the present study, the observed flying flocks varied greatly in size since it ranged between flocks of one or two individuals to flocks of more than 200 bird individuals. During the study period, the number of small flocks which contain one or two bird individuals formed $47 \%$ of the total number of observed flocks (3756 records) and 2\% of observed birds (143906 birds) and the number of individuals they contain (from 3 to 10 birds) were 
formed $36 \%$ of the total number of records and $5 \%$ of the total number of birds. The flock size ranging from (11 to 100) birds were formed $14 \%$ of the total number of records and $16 \%$ of the total number of observed birds. The flock size includes (101 to 200) birds were only formed 3\% of the total number of flocks and $29 \%$ of observed birds. The corresponding figures for large flocks which contain more than 200 individuals were $1 \%$ of bird records and $49 \%$ bird numbers respectively (Fig. 2).

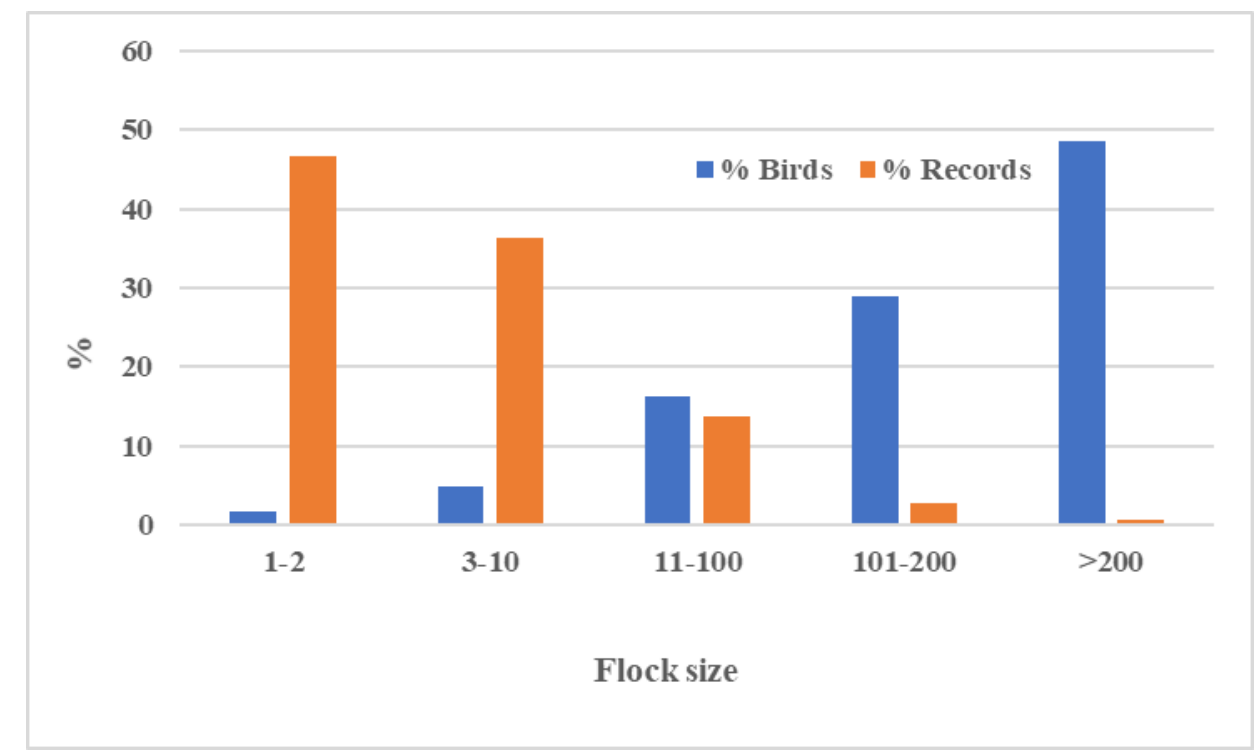

Fig. (2): Percentages of bird numbers and bird records calculated for different flock sizes in the study area during spring 2018

Daily changes in bird numbers and bird records: The percentage of records was higher during morning observation (from 8:00 am to 12:00 pm) since it formed about $70 \%$ of total records. The percentage of observed birds, 
on the other hand, was slightly higher during the afternoon hours $(12: 00 \mathrm{pm}$ to $4 \mathrm{pm}$ ) since it formed about $53 \%$ of the total number of birds (Fig. 3).

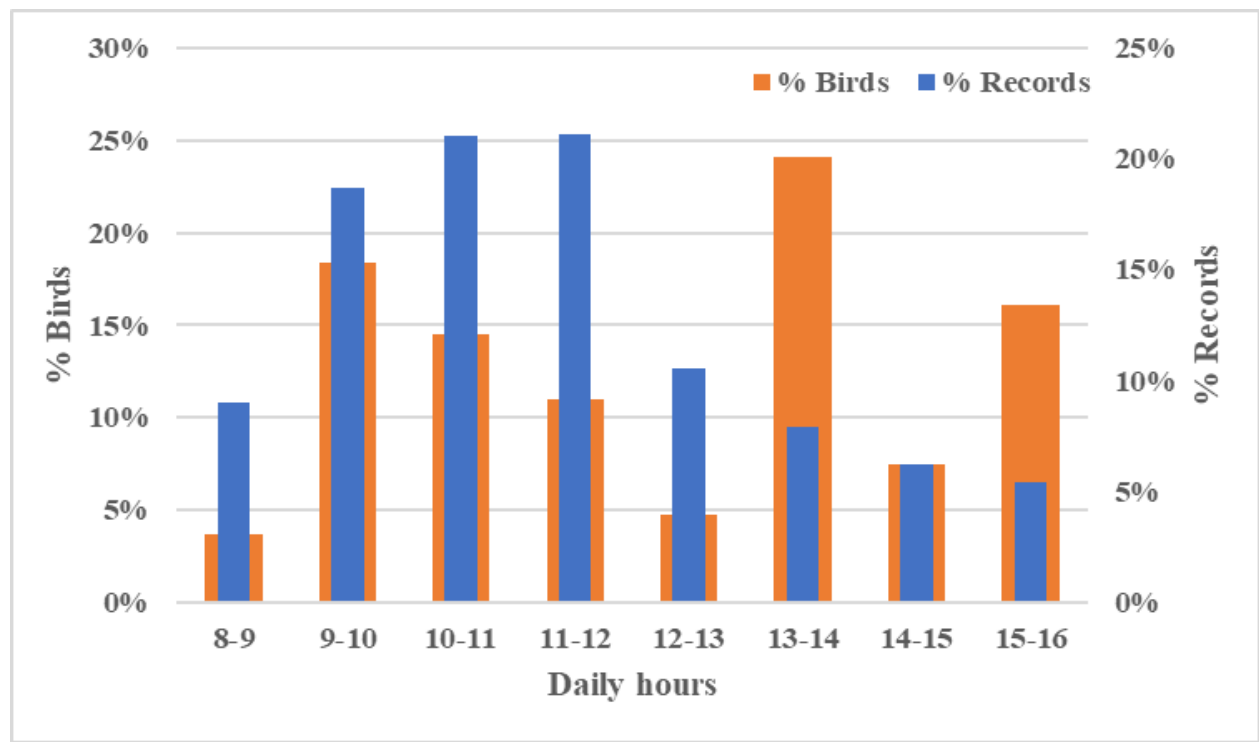

Fig. (3): Average migration rate in morning and evening survey hours for all observations in the study area

Weekly changes in bird numbers and bird records: The number of observed bird species and number of records were generally low in the first four weeks and the last two weeks of the study period. The highest percentage of bird numbers $(17.1 \%, 21.2 \%$, and $13.3 \%)$ were recorded in weeks 5,6 and 8 respectively. The highest percentages of records $(16 \%, 13 \%, 19 \%$ and $14 \%)$ were recorded in weeks 6, 7, 8, and 9, respectively (Fig. 4). 


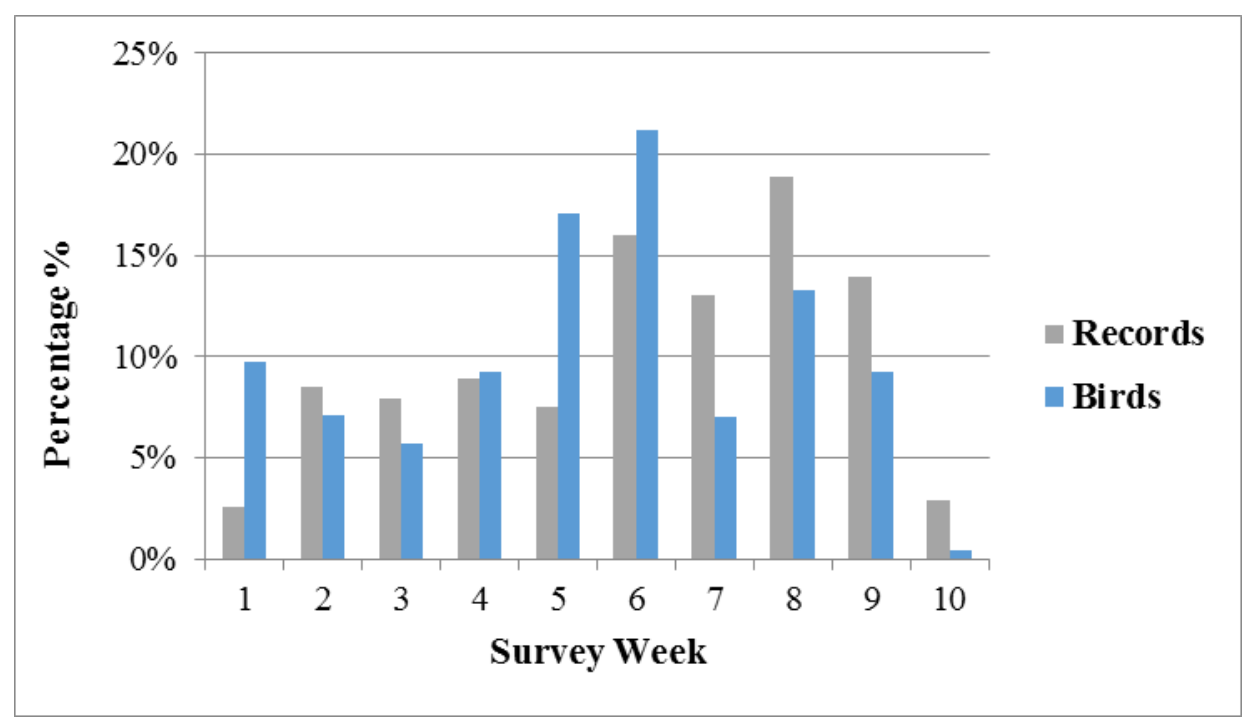

Fig. (4): Weekly percentages of numbers and records of birds observed in the study area from March $4^{\text {th }}-$ May $10^{\text {th }}$ during spring 2018

Flying altitudes of common bird species: In the present study, the white stork, steppe buzzard, Levant sparrowhawk, honey buzzard, black kite, and steppe eagle common bird species, were mostly recorded flying at altitudes of more than $200 \mathrm{~m}$ (Fig. $5 \mathrm{~A}$ and B). The white pelican, which is also a common bird species, flew at lower altitudes since a high percentage (69\%) of this bird was recorded flying at altitudes ranging from $100 \mathrm{~m}$ to $200 \mathrm{~m}$. 
Journal of Environmental Sciences (JES)

Faculty of Graduate Studies and Environmental Research, Ain Shams University

El-Gebaly et al.

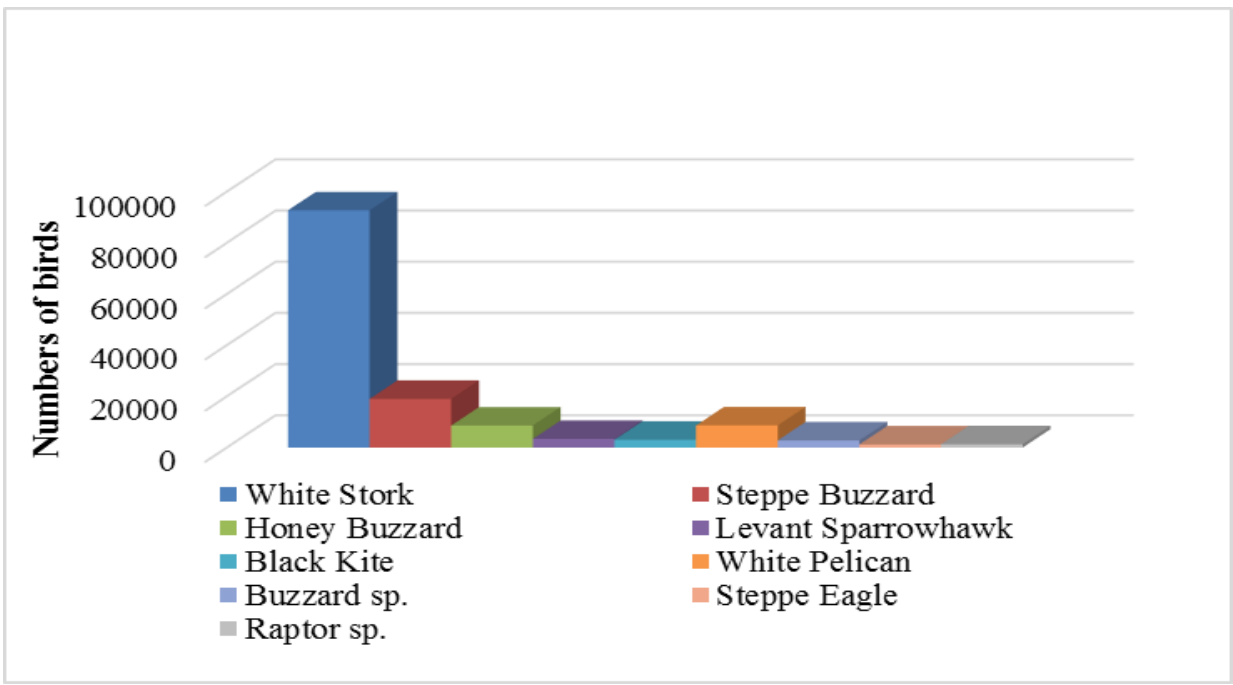

Fig. (5 A): Numbers of the most dominant birds recorded in the study area

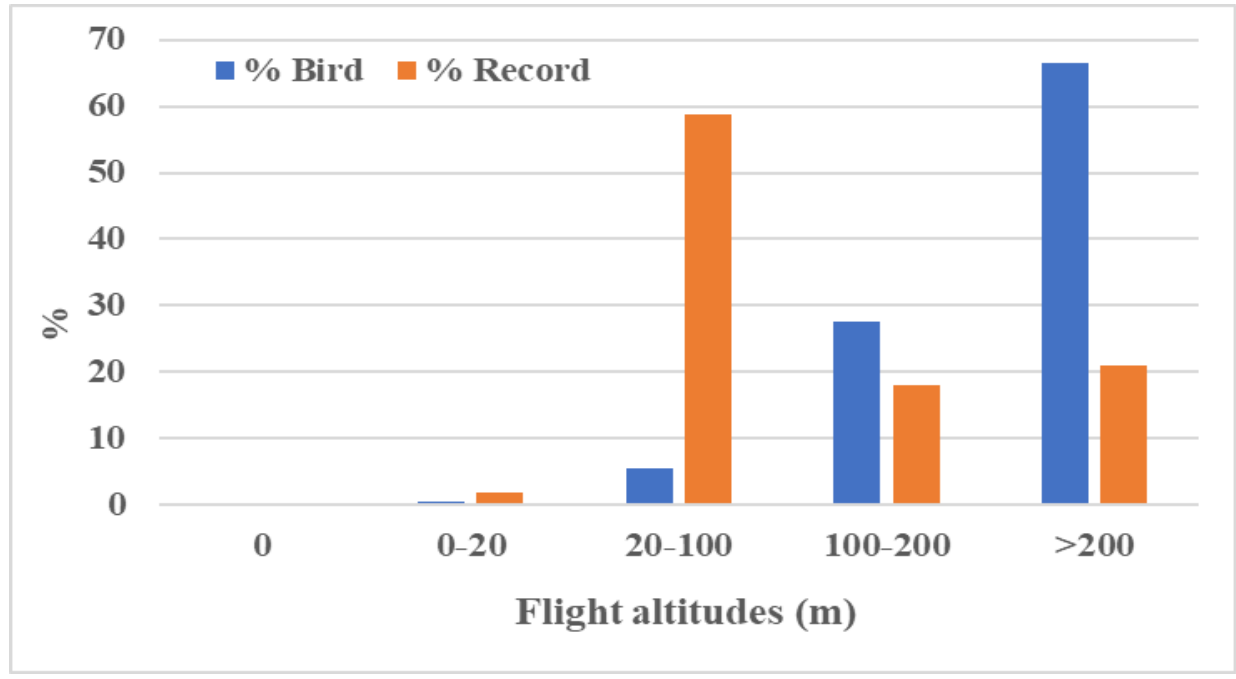

Fig. (5 B): Percentages of numbers and records of common migratory soaring birds flying at different altitudes in the study area

Vol. (50); Iss. (11); No. (4); Nov. 2021

ISSN 1110-0826

ONLINE ISSN 2636 - 3178 
Flying direction of migrating birds: During the study period, the direction of all bird species passing through the study area was determined. The dominant bird migration course was generally heading northward. Sixty-two percent of observed birds adopted northern $(\mathrm{N})$, northeastern $(\mathrm{NE})$, and northwestern (NW) directions, which is expected for northward spring migration. A considerable proportion of observed records (23\%) adopted an eastern direction of flight, and a lesser proportion of observed records (15\%) had a northeastern migration route (Figs. 6).

In all flight directions, the highest percentage of the bird's numbers has been recorded at more than $200 \mathrm{~m}$. Also, we recorded more than $20 \%$ of birds between 100-200m (Fig. 7). 
Journal of Environmental Sciences (JES)

Faculty of Graduate Studies and Environmental Research, Ain Shams University

El-Gebaly et al.

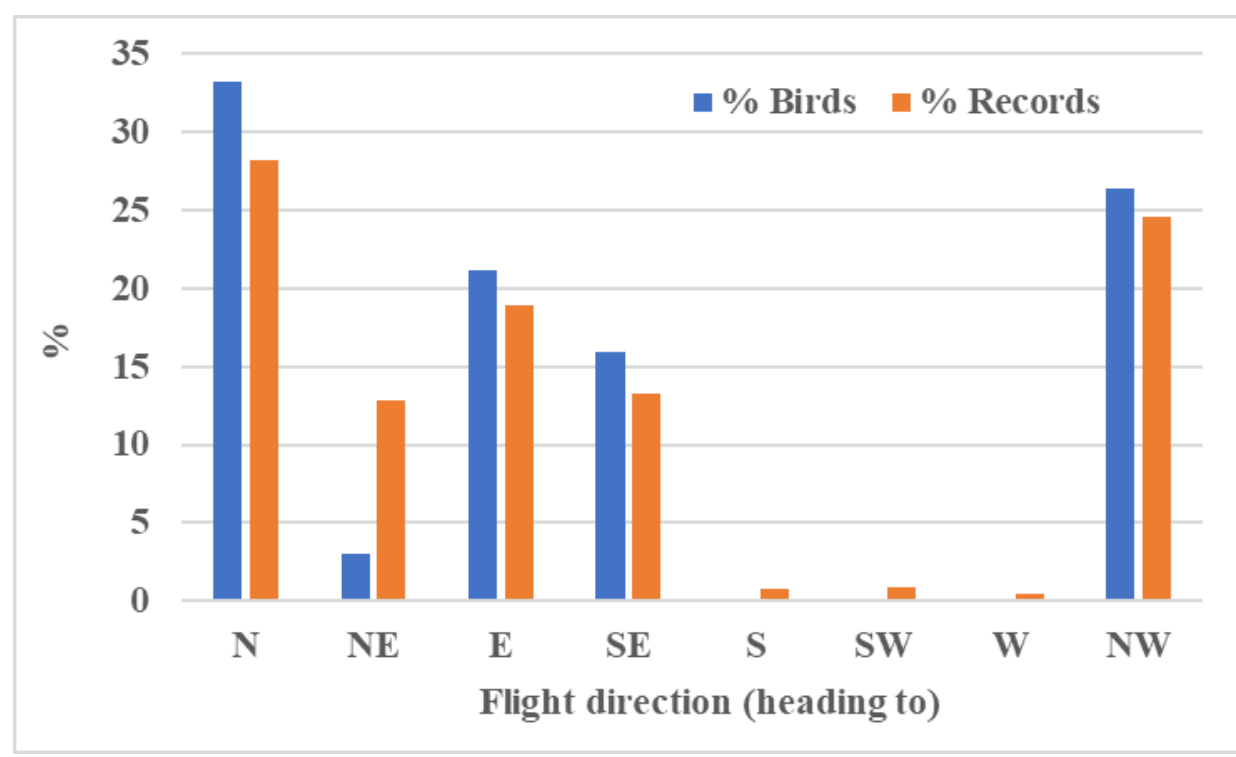

N, North; NE, Northeast; E, East; SE, Southeast; S, South; SW, Southwest; W, West; NW, Northwest.

Fig. (6): Percentage of flight direction of birds/records of soaring birds recorded in the study area 
Journal of Environmental Sciences (JES)

Faculty of Graduate Studies and Environmental Research, Ain Shams University

El-Gebaly et al.

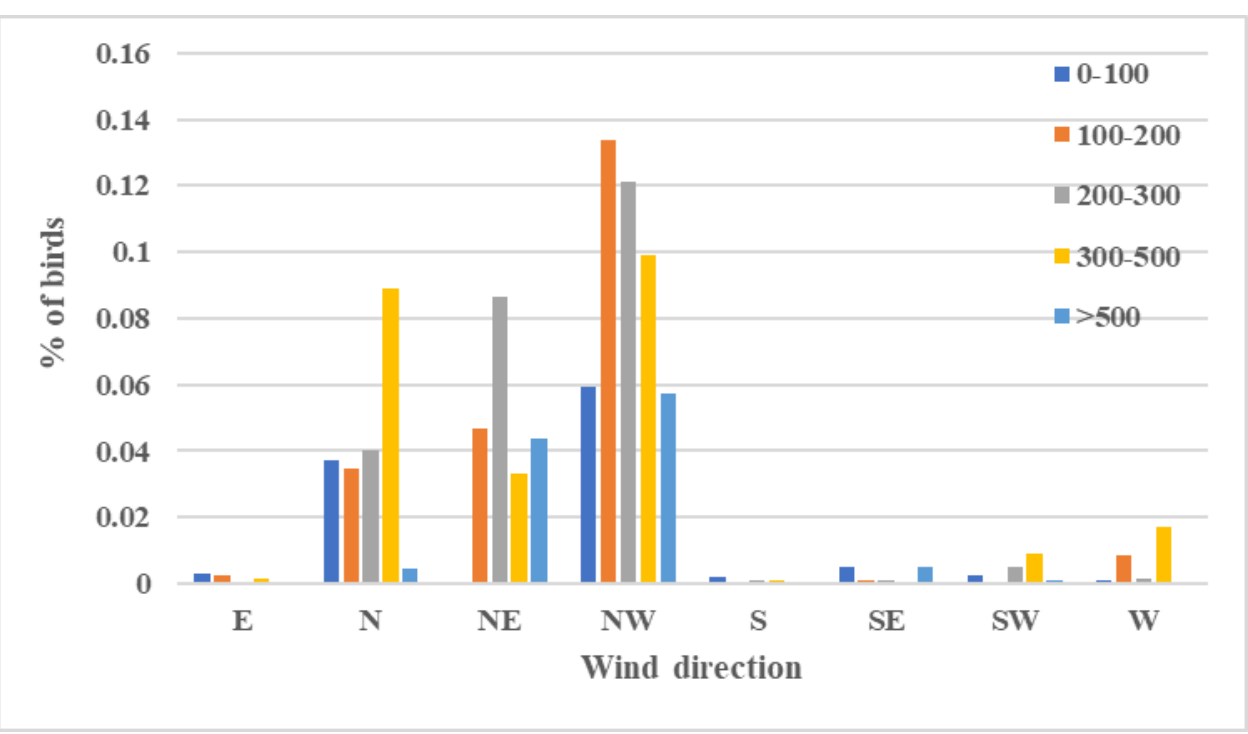

E, East; N, North; NE, Northeast; NW, Northwest; S, South; SE, Southeast; SW, Southwest; W, West.

Fig. (7): Percentage of birds flying at each flight direction at different flight altitudes to the overall recorded birds in the study area

\section{DISCUSSION}

The present study describes substantial migration of birds across the Eastern Desert of Egypt. In the spring; migratory birds are under the pressure of time as they must reach their summer breeding grounds early enough to successfully compete for a suitable breeding site. They have to mate, incubate eggs and raise young before they leave back to African wintering grounds the 
next autumn. Birds arriving too late or too exhausted will not be able to reproduce successfully (Hilgerloh, 2009).

In some studies, migratory birds did not show preference for special routes through the study area. Raptors mostly migrate individually or in small groups and show a somewhat regular migration pattern. Soaring birds (storks, pelicans, and cranes), on the other hand, mostly migrate in massive herds, thus producing very distinct regional fluctuations (Langston \& Pullan, 2003; Drewitt, \& Langston, 2006 \& Langston, 2006; Riad, 2020). While the researcher in this study indicated that soaring birds were recorded in vantage point 2 (VP2) at a far distance from the coast of the Gulf of Suez to have enough time to raise up and reach a considerable height to be able to cross the bay easily at its narrowest point at Ras Shukier or Ras Gharib.

The study results showed that many threatened species; i.e., steppe eagle, Egyptian vulture, greater spotted eagle, eastern imperial eagle, and pallid harrier, use this pathway of migration from Africa to Eurasia. Many recorded numbers were seen flying at altitudes less than 200 meters, which suggests that they will continue to migrate north and cross the Gulf from Ras Gharib or may continue to the end of the Gulf at the city of Suez. According to these results, some individual migrants observed to the south of the study area often move to Sinai at the latitude of El Gouna and the Malaha Valley rest area, the only freshwater valley. These results are in accordance with the study of Christensen \& Jensen which indicated that migrants heading to Suez mainly concentrate along the mountain range west of the Gulf. Most white storks that 
Journal of Environmental Sciences (JES)

Faculty of Graduate Studies and Environmental Research, Ain Shams University

El-Gebaly et al.

reach the southern end of Sinai continue northwest of the country along the coast of Sinai before starting to cross the sea, thus reaching the mainland of Egypt between Ras Gharib and Ras Gamasa (Christensen \& Jensen, 2002). However, more observations are needed to accurately determine their migration pathway (Grieve, 1996 \& Baha El Din, 1999).

Observations carried out during the present study showed that migrants fly along the foothills of the Red Sea Mountains and then to the coastal hills of Gabel Al Zeit or the coast adjacent to the northern area. Large portions of the population of bird species such as the white stork and this was in agreements with other studies (Creutz 1985; Schulz 1988; Goodman \& Meininger 1989 \& Berthold et al. 2001), levant sparrowhawk (Grieve, 1996 \& Baha El Din, 1999) and common crane regularly cross the Gulf of Suez. Consequently, many birds have no choice but to cross the study area. Other bird species such as the lesser spotted eagle, a species that avoids any sea crossing, continue to migrate to Suez (Grieve, 1996; Meyburg et al. 2002; Riad et al. 2020).

Migration patterns are highly variable from one year to another as they are highly dependent on weather conditions. This way, variation in weather conditions in the upcoming years may cause changes in the migratory patterns compared to what was recorded in previous years. Future studies should describe other areas in the flyway other than the current study area that soaring birds use to cross the Suez Canal to South Sinai. Future studies should also explore the complex migration patterns of soaring birds that 384

Vol. (50); Iss. (11); No. (4); Nov. 2021

ISSN 1110-0826

ONLINE ISSN 2636 - 3178 
migrate through the Rift Valley/Red Sea Flyway, especially storks, pelicans and crane, during different weather conditions.

\section{CONCLUSION}

This study indicates the significance of the Gabel Al Zeit as an important bottleneck for soaring bird spring migration.

The dominant bird migration course was generally heading northward. Sixty-two percent of observed birds adopted Northern $(\mathrm{N})$, North Eastern (NE), and North-Western (NW) directions, which is expected for northward spring migration.

Observations of this study showed that migratory soaring birds fly along the foothills of the Red Sea Mountains and then head for the coastal hills of Gabel Al Zeit or the coast adjacent to the northern area, especially in those species such as White Stork and Levant Sparrowhawk. These results clarify the importance of the study area as a bird migration corridor that highlighted the potential impacts and required actions to protect migratory birds. Although this number significantly represents a high portion of spring migration, the number of birds passed over Gabel Al Zeit does not reflect the real number as many migrating birds cross different areas along the flyway.

In conclusion, soaring bird migration monitoring continuation at this site is important for recording population dynamics and behavior to set the required action plans. 


\section{ACKNOWLEDGMENTS}

We would like to thank a group of ornithologists and bird watchers who helped us to monitor the migration and collect some data for the study. Also, we thank the Egyptian New and Renewable Energy Authority (NREA), Migratory Soaring Birds project in Egypt and Egyptian Environmental Affairs Agency (EEAA) for their support and facilitation of obstacles during the study.

\section{REFERENCE}

Baha El Din, S. (1999): Directory of important bird areas in Egypt. Cambridge, UK: BirdLife International.

Bergen, F. (2007): Ornithological expert opinion as a part of the feasibility study for a large windfarm at Gulf of Zayt, Egypt. Report to MVV DECON Gmbh. Dortmund.

Bergen, F. and Gaedicke, L. (2013): Draft report on the bird migration study at the Gulf of Suez (300 km area) at Ras Gharib in the Arab republic of Egypt. Report to New \& Renewable Energy Authority (NREA).

Berthold, P.; Van Den Bossche, W.; Fiedler, W.; Gorney, E.; Kaatz, M.; Leshem, Y.; Nowak, E. and Querner, U. (2001): Der Zug des Weißstorchs (Ciconia ciconia) eine besondere Zugform auf Grund neuer Ergebnisse. J. Ornithol. 142, 73 -92.

CarlBro, (2010): Bird migration study in El-Zayt, Egypt. Report from bird migration studies autumn 2008 and spring 2009. Report to Italgen - Italcementi Group. 
Christensen, K. D. and Jensen, F. P. (2002): Atlas of bird migration at the Gulf of Suez, Egypt. Copenhagen, Denmark: Ministry of Foreign Affairs, Danida.

Creutz G. (1985): Der Weißstorch (Ciconia ciconia). A. Ziemsen Verlag, Wittenberg Lutherstadt. Kosicki J., Sparks T., Tryjanowski P. 2004.

Drewitt, A. L. and Langston, R. H. W. (2006): Assessing the impacts of wind farms on birds. Ibis 148: 29-42.

Goodman, S. M. and Meininger, P. L. (eds.) (1989): The birds of Egypt. Oxford: Oxford University Press

Grieve, A. (1996): Spring raptor movements at Gebel el Zeit, Egypt. Sandgrouse 18: 61-63. J. f. Ornithologie 142: 73-92.

Hilgerloh, D. (2009): The desert at Zait Bay, Egypt: a bird migration bottleneck of global importance. Bird Conservation International BCI 19, 338-352(04) DOI:10.1017/S0959270909008430

Langston, R. H. W. (2006): Wind, fire and water: renewable energy and birds. Proceedings of the British Ornithologists' Union annual spring conference 2005, University of Leicester, 1-3 April 2005. Ibis 148: 13 .

Langston, R. H. W. and Pullan, J. D. (2003): Windfarms and birds: An analysis of the effects of windfarms on birds, and guidance on environmental assessment criteria and site selection issues. TPVS/Inf 12.

Meyburg, G. U.; Matthes, J. and Meyburg, C. (2002): Satellite-tracked Lesser Spotted Eagle avoids crossing water at the Gulf of Suez. Brit. Birds 95: 372-376. 
Moreau, R. E. (1972): The Palaearctic-African Bird Migration Systems. Academic Press. London, UK. on environmental assessment criteria and site selection issues. Cambridge, UK: BirdLife International on behalf of the Bern Convention, Strasbourg (TPVS/Inf 12).

Newton, I. (2008): The migration ecology of birds. Heidelberg: Academic Press as imprint of Elsevier.

Riad, S. A. (2020): Quantity of Spring Migration of Migratory Soaring Birds Over the Eastern Desert of Egypt. Egyptian Academic Journal of Biological Science (B. Zoology), 12(2):161-171.

Riad, S. A.; Al-Mongy, M. and Abdel-Halim, I. E. (2019): Movement Patterns of the Black Kite (Milvus migrans) During Spring Migration over Rift Valley/Red Sea Flyway, Gulf of Suez, Egypt. Academic Journal of Biological Science (B. Zoology), 11(3): 145- 155. DOI: $10.21608 /$ eajbsz.2019.65676

Riad, S. A.; Al-Mongy, M.; Abdullah, A. and Abdel-Halim, I. E. (2020): Recording of The Spring Migration of Soaring Birds Through Gebel El Zeit, Eastern Desert, Egypt. Egypt. Egyptian Journal of Zoology, -. doi: 10.12816/ejz.2020.49156.1043

Schulz, H. (1988): Weißstorchzug. O”kologie, Gefa“hrdung und Schutz des Weißstorchs in Afrika und Nahost. Weikersheim, Germany: WWF Umweltforschung 3.

Scottish Natural Heritage, (SNH) (2010): Survey methods for use in assessing the impacts of onshore windfarms on bird communities. Available from: htt://www.snh.gov.uk/docs/C278917.pdf

Sutherland, W. (2006): Ecological Census Techniques: A handbook. Cambridge University Press. 


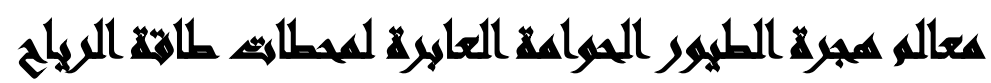

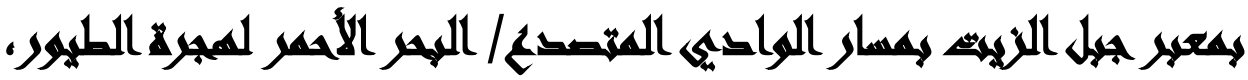 المصراء الثراهية - مصر
}

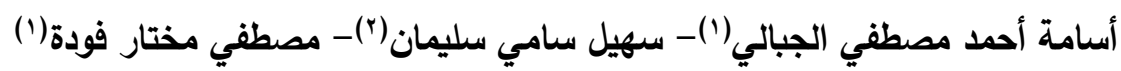

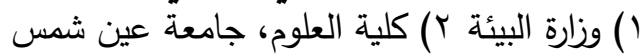

\section{المستخليف}

يهذف هذا البحث إلي دراسة أشكال الهجرة ودراسة أعداد وأنواع الطيور الحوامة المهاجرة التي

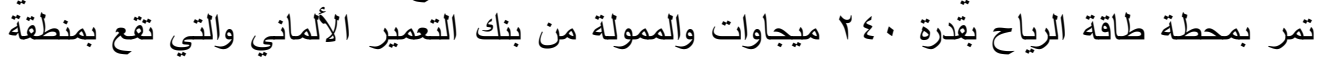

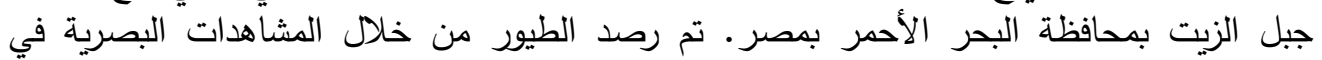

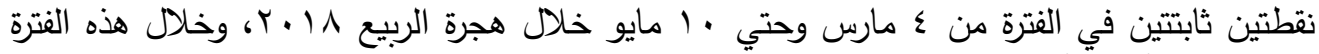

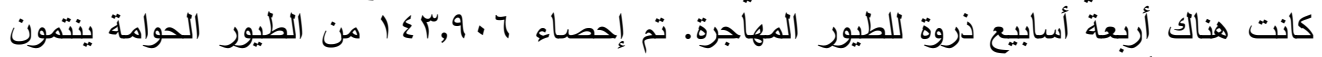

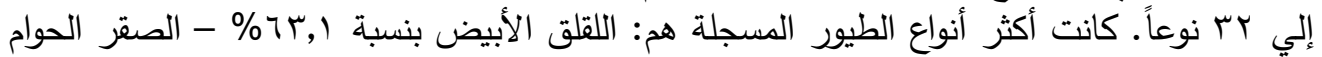

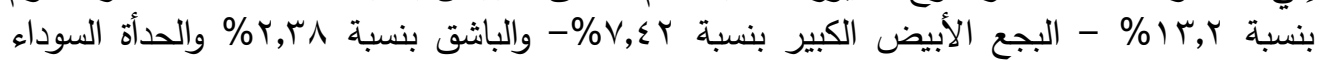

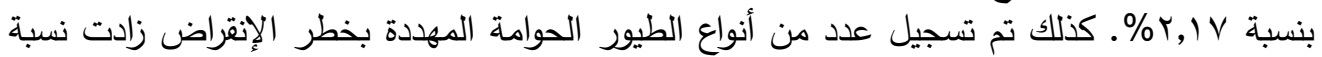

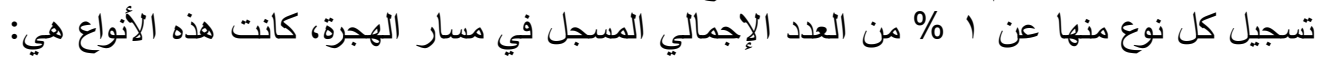

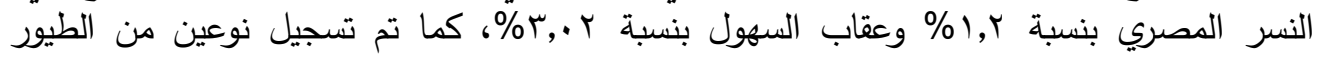

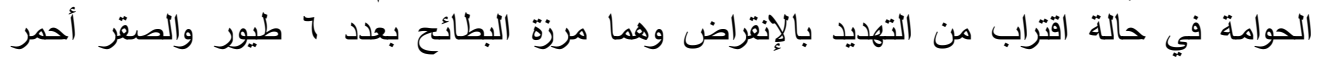

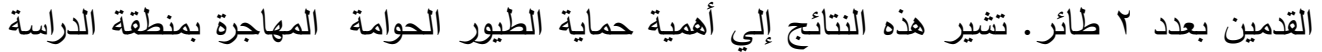
حيث تعتبر كمدر رئيسي لهائ. الكلمات المفتاحية: الطيور الحوامة المهاجرة - محطات طاقة الرياح - مسار هجرة البحر الأحمر

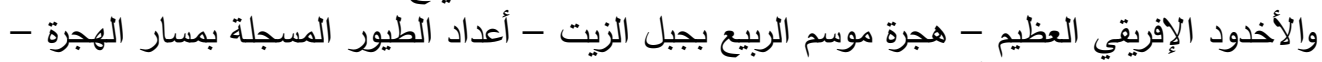
عقاب السهول - اللقلق الأبيض. 